\title{
THE INFLUENCE OF WORKSHOP MANAGEMENT ON THE SKILLS OF STUDENTS OF SMK NEGERI 3 TORAJA UTARA
}

\author{
Harlan Mardos 1 伲, Bernadetha Nadeak 2 四 \\ 1,2 Magister of Education Management Department, Postgraduate Program, Universitas Kristen \\ Indonesia, Jakarta
}

DOI: https://doi.org/10.29121/granthaalayah.v9.i1.2021.3285

Article Type: Research Article

Article Citation: Harlan Mardos, and Bernadetha Nadeak. (2021). THE INFLUENCE OF WORKSHOP MANAGEMENT ON THE SKILLS OF STUDENTS OF SMK NEGERI 3 TORAJA UTARA. International Journal of Research GRANTHAALAYAH, 9(1), 351-357. https://doi.org/10.29121/granthaa layah.v9.i1.2021.3285

Received Date: 25 December 2020

Accepted Date: 31 January 2021

Keywords:

Skills

Workshop Management Vocational

\begin{abstract}
This research aims to find out the influence of workshop management on SMK Negeri 3 Toraja Utara skills. This research is a quantitative research survey: systematic scientific research on parts and phenomena and their relationships. The design was chosen because following the nature of the research conducted at first. The research on the relationship between workshop management was conducted to improve students' skills at SMKN 3 Toraja Utara. The research results explained that there is an influence of workshop management on the skills of students of SMK Negeri 3 Toraja Utara, based on the results of the t-test of 5,623 with a significant 0.035 .
\end{abstract}

\section{INTRODUCTION}

Based on data from bps unemployment in Indonesia as of February 2019 is 17.2 million people. From the data obtained, Vocational High School alumni are those who do not work contributed to the high unemployment rate. This data shows that most vocational school graduates cannot be independent and rely only on other parties' jobs, resulting in higher unemployment in Indonesia.

Education Development Index (EDI), an education index released by UNESCO, states that Indonesia currently ranks 69th out of 127 countries[1]. It clarifies that vocational school graduates cannot directly have jobs, due to the low quality of education in Indonesia, especially at the secondary education level. From both references, it proves that the quality of education in Indonesia is still not satisfactory.

The vocational high school which was an education level whose graduation is expected to work immediately, but the curriculum at this time has not fully supported the readiness of STM graduates to be able to work immediately, so this causes a high graduation rate but is not balanced with the rate of employment absorption. Besides, the quality of secondary education in Indonesia is also still deficient from the last data obtained from BPS, in 2019 , it was mentioned that the average exam results at the high school level have a tendency to score lower than

(C) 2021 The Author(s). This is an open access article distributed under the terms of the Creative Commons Attribution License, which permits unrestricted use, distribution, and reproduction in any medium, provided the original author and source are credited. 
the previous year. As many as 601 students did not pass the total number of 1,106,104 test-takers[1], Based on the compass data, Indonesia's quality of education based on graduation rates is still relatively low.

To reduce the unemployment from a high school education level, the government must make a continuous improvement of existing education quality. The end goal is to improve the quality of graduates to be able to compete for jobs. The inability of vocational school graduates to be able to jump directly into the field of work explains that the mandate of the Law of the Republic of Indonesia Number 20 of 2003 on the National Education System, especially explaining that vocational is a secondary education that prepares students to work in specific fields. The same thing is also explained in one of education's objectives at the vocational high school level. It is based on the regulation of the Minister of National Education (Permendiknas) No. 22 of 2006 is to improve intelligence, knowledge, personality, noble character, and competence of learners in order to live independently and be able to follow an education at a higher level that is adjusted to the vocational program. It is one of the fundamental reasons for the quality of education, especially in vocational schools, to be improved.

The establishment of vocational schools in Indonesia is based on the thinking of Charles Prosser, who stated that there are 16 principles of the program in succeeding the level of education at the vocational level, but in reality, in the vocational school field is constrained in terms of education management caused by ineffective, and efficient [2].

To improve vocational school graduates who will be ready to work immediately requires and improvement on the quality of education, ranging from the middle to the upper levels [3]. It explains that vocational high school graduates have not significantly influenced the reduction in Indonesia's unemployment rate. The emergence of inequality between the number of graduates and the workforce's needs is one of the causes. It encourages the importance of each level of education has particular competencies and skills when working in a company or selfentrepreneurship [4].

As mentioned in the previous paragraph, it is the leading cause of vocational school graduates looking for work. That there is a significant gap between the material taught and the Paktika in employment [5]. It shows that there is still a gap between theory and practice obtained in schools with implementation in work. The primary purpose of dual system education activities, which is currently known as industrial work practices, is to develop the professionalism and competencies achieved and applied to the real work environment. Industrial work practices give an idea to students how good the working conditions are. To improve competence is held in industrial work by establishing cooperation between schools and industries.

Another thing that affects competency improvement is the lack of training for vocational school students, among others, there are still few companies that are willing to accept vocational school students for internships. Hamrlik stated that schools rarely provide any special training because in public vocational schools provide training materials into work practice [6]. The school material is training that has been integrated into the curriculum, namely practical learning at the secondary vocational level with various programs following the vocational selected by the student concerned. It can be concluded that the training experience is the result of a practical learning process in school.

The critical role of vocational proficiency to the results of competencies is among others, contributed from the training experience that students have while undergoing vocational skills. It is further explained that students' vocational skills will differ according to their chosen field of work [7]. It strengthens the perception of vocational proficiency possessed by students will give importance to student competence.

Based on the description as mentioned above, it is explained that students' competence is influenced by factors, industry work practices, coaching experience, and vocational skills that must be mastered by students so that the requirement for students to graduate must have the skills or skills required in the real world of work [8].

The three variables above, namely industrial work practices, trainer experience, and vocational skills, are included in the basis of the program initiated by Charles Prosser on points 10,11, and 12. There is a lack of experience of students in real work, inadequate training and still not good vocational skills that students have because of the lack of willingness to accept apprentices is one of the causes [9]. From this, it can be drawn that workshop management is related to vocational school students

' skill level.

One of the workshop's problems is that there is still no regular schedule in the implementation. Some workshops were carried out monthly, but the other workshops were carried out three times a month. In addition to the irregular, the schedule is also influenced by the lack of complete facilities and infrastructure, and teachers also have problems providing teaching materials [10]. From the above problems where the implementation of irregular workshops in 
Harlan Mardos, and Bernadetha Nadeak

the number of each month, can be seen if the workshop management is not carried out as needed, students' skills become not optimal.

\section{THEORETICAL REVIEW}

According to Uno, skills can apply for work quickly and meticulously. In this sense, it usually tends to be on psychomotor activity [11]. Besides, according to Hamalik, the understanding of skills requires practice and can be interpreted as the activity's implications [12]. In line with each of these views, Hamalik defines skills as the capacity needed to carry out some of the tasks that develop the exercises' results, and the experience gained [13]. In that case, Ananda added that in addition to the exercises necessary to develop abilities, skills also require basic skills to do the job efficiently and precisely. According to Helmawati, skills can be categorized into four parts, namely: (1) Basic literacy skills, (2) Technical skills, (3) Interpersonal skills, (4) Problem skills [14]. Based on the concept of lifelong learning education, the term workshop appeared. The term workshop can be explained to improve skills and competencies in specific fields carried out quickly.

Hamrlik defines the workshop as a systematic effort to master competencies, regulations, concepts, or ways of behaving that impact improving performance [15]. Furthermore, Ananda argues that the workshop is a learning activity of teaching and drills to stamp a particular competence or work efficiency level as the workshop's output, and expected to provide a quick response, appropriate and following the situation faced [16].

Proper and professional management of workshops can provide functional meaning to individuals, organizations, and communities. The workshop does need to be organized. Therefore, management in the workshop is needed as a systematic and planned effort to optimize all workshop components to achieve the workshop's objectives effectively and efficiently. The management component itself consists of curriculum, human resources, facilities/infrastructure, and cost. Systematic and planned training management includes planning, implementation, supervision (control), and evaluation, especially concerning the organization, programs, resources, and financing. At the same time, the purpose of organizing workshops, in general, is to improve the results of professional workshops.

In the Great Dictionary of Bahasa Indonesia, students' understanding means children (studying, attending school). Meanwhile, according, learners in a broad sense are everyone associated with the lifelong educational process, while in a narrow sense, every student learns in school [17].

According to Hamalik, students are one component in teaching and teacher factors, objectives and teaching methods. As one component, it can be said that the student is the essential component among the other components. Students or students are the main subjects in education, and students or children are "unique" individuals who have potential and experience development [18].

To obtain an objective understanding of learning requires an understanding of the learning. The basic word for learning is learning. Learning is a process of changing behaviour because of individual interaction with the environment and experience [19]. In a narrow sense, learning is a process or way done to do the learning activity. In a broad sense, learning is a systematic and systemic process or activity, which is interactive and communicative between educators and learners, learning resources with an environment to create a condition that allows the learning actions of learners, both in the classroom and outside the classroom, attended by teachers physically or not, to master the competencies that have been determined. In line with Ananda, learning is a process that results in behavioural adjustments [20].

Learning is a process to gain motivation in knowledge, skills, habits, and behaviour; learning is also the mastery of knowledge or skills obtained from instruction. Meaningful learning is the first adjustment is to get the right response to solve the problem. Learning is not about repeating things but understanding or gaining insights.

The paradigm of the education system that was initially based on traditional by relying on face-to-face turned into an education system that is not limited by space and time with a touch of the world of information technology, especially cyberspace. The cyber-based education system referred to as e-learning [21].

\section{RESEARCH METHODS}

This research is a quantitative research survey: systematic scientific research on parts and phenomena and their relationships. The survey research is "a quantitative study using the same structured or systematic questions to many people, for then all the answers obtained by researchers are recorded, processed and analyzed." [22]

$\underline{\text { International Journal of Research -GRANTHAALAYAH }}$ 
The design was chosen because, by the nature of the research conducted first, research on the relationship between workshop management was conducted to improve students' skills at SMKN 3 Toraja Utara. The data collected in this study related to the application of workshop management and improving student abilities. The data is collected simultaneously. In a relatively short time, both data obtained in this study are then processed according to the type of conclusions desired, namely; looking for interconnected relationships and the amount of influence between variables.

This research was designed to use questionnaires as a data collection tool. That will be given to respondents in this study. The scale used in the research on workshop management variables is the Likert scale by looking at respondents' responses regarding selecting materials, implementing workshops, maintaining existing facilities and infrastructure and the plates/tutors who teach workshops. The Likert Scale is a research scale used to measure attitudes and opinions. On this Likert scale, respondents were asked to complete a questionnaire requiring them to show their level of approval of a series of questions. This study's questions or statements are usually referred to as research variables and set specifically by researchers. The scale used is the ordinal scale.

\section{RESULTS AND DISCUSSION}

Validity testing is performed using Confirmatory Factor Analysis (CFA), with SPSS for Windows version 24.0. Confirmatory Factor Analysis (CFA) must be met, as it is one of the requirements to analyze models with Structural Equation Modelling (SEM). The results state that all question items are declared valid because each question item that is an indicator of each variable has been extracted correctly and has a loading factor of $>0.50$.

Normality tests use lilliefors tests performed parametrically using the average estimators of standard deviations. The sample to be tested has zero hypotheses and comes from a normally distributed population against hypotheses that have abnormal distributions [20].

Table 1: Test of Normality

\begin{tabular}{|c|c|c|}
\hline Variable & Result & Sig \\
\hline Management Workshop & 0,215 & 0,05 \\
Keterampilan Protest & 0,200 & 0,05 \\
Keterampilan Posttest & 0,111 & 0,05 \\
\hline
\end{tabular}

Source: Processed Primary Data, 2020

Normality test results as shown gave results for workshop management (0.215), students' skills before getting treated (0.200), and student skills after getting fair treatment (0.111) using Kolmogorov-Smirnov test, showing significant value above 0.05 so data used distributed normally.

Homogeneity test was done with Barlet test, and this test was done to estimate the average difference and test the similarity or difference of two averages. It should be emphasized that the assumption that both groups have the same variance so that the activities of assessing and testing can take place. Homogeneity test results using Barlet are indicated by Table 2

Table 2: Homogeneity Test

\begin{tabular}{|c|c|c|}
\hline & Levene Statistic & Sig. \\
\hline Protest & 3,770 & 0,064 \\
PostTest & 0,793 & 0,615 \\
\hline
\end{tabular}

Source: Processed Primary Data, 2020

The significance value shown shows the values 0.064 and $0.615>0.05$, so the data used is homogeneous data or the data has the same variant.

Simple regression liner phase I to see the influence before workshop management is applied to student skills. 
Table 3: Test Result t Equation 1

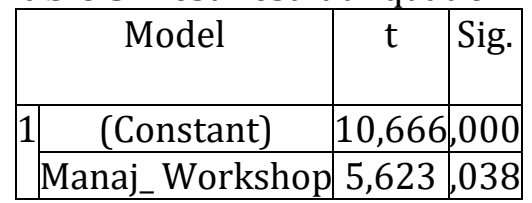

Source: Processed Primary Data, 2020

Table 3 can be explained that workshop management has a positive and significant effect on students' skills. It can be seen from the significance score of $0.038>0.05$. These results prove the hypothesis that there is an influence of workshop management on student skills is proven.

Table 4: Result of Determinants Test

\begin{tabular}{|c|c|c|c|}
\hline Model & R & R Square & Adjusted R Square \\
\hline 1 & $910^{\mathrm{a}}$ &, 828 &, 808 \\
\hline
\end{tabular}

Source: Processed Primary Data, 2020

R2 test obtained results of 0.828; this means that students' skills before treatment explained by Variable management workshop by $82.80 \%$ and the remaining $17.20 \%$ explained other Variables outside the research model. Simple linear regression phase II to see the influence before workshop management is applied to student skills.

Table 5: Test Result t Equation II

\begin{tabular}{|c|c|c|}
\hline \multicolumn{2}{|c|}{ Model } & Sig. \\
\hline 1 & (Constant) & $9,303,000$ \\
\hline \multicolumn{2}{|c|}{ Manaj_Workshop $8,055,022$} \\
\hline
\end{tabular}

Source: Processed Primary Data, 2020

Table 5 can be explained that workshop management has a positive and significant effect on students' skills. It can be seen from the significance value of $0.022>0.05$. These results prove the hypothesis that there is an influence of workshop management on student skills is proven.

Table 6: Result of Determinants test

\begin{tabular}{|c|c|c|c|}
\hline Model & R & R SquareAdjusted R Square \\
\hline 1 &, $969 a$ &, 899 &, 839 \\
\hline
\end{tabular}

Source: Processed Primary Data, 2020

R2 test obtained results of 0.899; this means that students' skills before treatment explained by Variable management workshop by $89.90 \%$ and the remaining $11.10 \%$ explained other Variables outside the research model.

From the results of the study, it is known that there is a significant difference in students' skills between students with workshop management and students without workshop management implementation. The results confirm that management or management in the sense that starts from scheduling, maintenance of facilities and infrastructure, supervision of the implementation of workshops, and analysis of the implementation of workshops can improve students' skills, which will make students ready to work[22].

This study has several weaknesses, including the absence of control groups to not compare between before and after treatment of free Variables. It cannot be said that the improvement of students' skills is influenced by workshop management, but other things affect the learning process. Therefore, it is necessary to control the learning by giving treatment as students follow the lesson and record a summary of the material described by the supervisor.

The study results showed that workshop management could improve students' skills in using equipment and repair equipment in the workplace. The results of this study are in line with previous research conducted by $\mathrm{H}$ 
Winnarko and S Hamidah. Management of on-the-job training (OJT) in the culinary skill study program of SMK in Yogyakarta, 2019 UNY. In this study, Winnarko and Hamidah suggested a strong relationship between apprentice training conducted on student skills.

The results obtained in this study are also in line with previous research conducted by Indri Tolo, Jantje L. Sepang, and Lucky 0.H. Dotulong. The influence of work skills discipline work and work environment on employee performance at the department of youth and sports (Diaspora) Manado, 2016. Both studies, both conducted by Indri, et al. and this study saw the importance of training on skill-enhancing, the main differences of the two types of research were applied to the research object, namely employees and students. In the research conducted by Indri, et al., the more and quality of training will provide improved employee skills that impact better performance.

Tri Wulaningrum also conducted other research in line with this research. Soft Skills Profile of Vocational School Students in Yogyakarta City for Entering the Industrial World. 2019 [25; 26]. In this research, Tri stated that soft skills improvement could be made by intensive training so that the sign of the aware ability of the trainees can continue to increase. The difference with the research that will be done lies in variable independent if in Tri Wulaningrum research, using internships in this research training is done.

\section{CONCLUSIONS}

One of the main problems of vocational school graduate students at this time is the competence to the world of work that is lacking, in addition to the individual factors of students, the school also contributes in the lack of competitiveness of students, such as incomplete practical facilities and infrastructure, the management of workshops that have not been carried out correctly. Combining these factors is one of the weak points in the vocational education system at this time. This study analyses how workshop management influences improving students' skills to become ready to enter the job market. From the results of the analysis and discussion as stated in the previous chapter, it can be concluded that there is an influence of workshop management on the skills of students of SMK Negeri 3 Toraja Utara, based on the results of the t-test.

Suggestions that can be presented based on the results of research and discussion are to the school, is expected to upgrade the equipment that is considered outdated, such as welding tools and machine test equipment, to fit the one used in the world of work seriously. Besides, the school is also expected to schedule better in implementing workshops, not only on the workshop schedule but also on the materials delivered. It is also expected that better cooperation with the company will be established to more easily do internships, as part of the vocational school curriculum.

\section{SOURCES OF FUNDING}

This research received no specific grant from any funding agency in the public, commercial, or not-for-profit sectors.

\section{CONFLICT OF INTEREST}

The author have declared that no competing interests exist.

\section{ACKNOWLEDGMENT}

None.

\section{REFERENCES}

[1] Arsyad, A. (2016). Media Pembelajaran. PT Raja Grafindo Persada.

[2] Nadeak, B., \& Naibaho, L. (2019). Managing Lecturers' Competence Development at Universitas Kristen Indonesia.

[3] Rifa'I M, W. C. (2016). Dasar-Dasar Manajemen Mengoptimalkan Pengelolaan Organisasi Secara Efektif dan Efisien. Perdana Mulya Sarana. 
[4] Tyas, E. H., \& Naibaho, L. (2019, November). The urgency of entrepreneurship learning in the industrial age of 4.0. In Journal of Physics: Conference Series (Vol. 1387, No. 1, p. 012032). IOP Publishing.

[5] Bernadetha Nadeak, 2019. Manajemen Pelatihan dan Pengembangan SDM. UKIPRESS

[6] Hamalik, O. (2016). Perencanaan Pengajaran Berdasarkan Pendekatan Sistem. Ganesha

[7] Hamalik, O. (2017). Dasar-dasar Pengembangan Kurikulum. PT Remaja Rosdakarya.

[8] Sormin, E., Julianti, K., Nadeak, B., \& Naibaho, L. (2019). Use of construction inquiry learning model to improve students' interest in grade XI SMA Angkasa 2 in coloid materials. PEOPLE International Journal of Social Sciences, 5(2), 908-917.

[9] Naibaho, L. (2019). The Integration of Group Discussion Method Using Audio-Visual Learning Media toward Students'learning Achievement on Listening. International Journal of Research-Granthaalayah, 7(8), 438-445.

[10] Naibaho, L. (2019). Teachers'roles on English Language Teaching: A Students Centered Learning Approach. International Journal of Research-Granthaalayah, 7(4), 206-212.

[11] Uno, H. B. (2016). Teori Motivasi dan Pengukiurannya. PT. Bumi Aksara.

[12] Ananda, R. A. (2018). Pembelajaran terpadu karakterstik, Landasan, Fungsi, Prinsip dan Model. LPPPI

[13] Helmawati. (2019). Pembelajaran dan Peinilaian Berbasisi HOTS (Higher order thingking skill). PT. Remaja Rosdakarya.

[14] Arikunto S. (2016). Presedur Penelitian Suatu Pendekatan Praktek. Rineka Cipta.

[15] Bernadetha Nadeak. (2020). Efektivitas Distance Learning Menggunakan Media Sosial Selama Masa Pandemi COVID-19: A Case of Universitas Kristen Indonesia. International Journal of Advanced Science and Technology, 29(7), 1-15.

[16] Bernadetha Nadeak, 2019. Manajemen Sumber Daya Manusia Pendidikan Era Industri 4.0. UKIPRESS.

[17] Tyas, E. H., \& Naibaho, L. (2020). Building Superior Human Resources through Character Education. TEST Engineering \& Management, 83, 11864-11873.

[18] Tyas, E. H., \& Naibaho, L. (2019, November). The urgency of entrepreneurship learning in the industrial age of 4.0. In Journal of Physics: Conference Series (Vol. 1387, No. 1, p. 012032). IOP Publishing.

[19] Nadeak, B., \& Naibaho, L. (2019, November). Investigating the effect of learning multimedia and thinking style preference on learning achievement on anatomy at Universitas Kristen Indonesia. In Journal of Physics: Conference Series (Vol. 1387, No. 1, p. 012116). IOP Publishing.

[20] Tyas, E. H., \& Naibaho, L. (2021). HOTS Learning Model Improves the Quality of Education. International Journal of Research-GRANTHAALAYAH, 9(1), 176-182.

[21] Nadeak, B., Juwita, C. P., Sormin, E., \& Naibaho, L. (2020). Hubungan kemampuan berpikir kritis mahasiswa dengan penggunaan media sosial terhadap capaian pembelajaran pada masa pandemi Covid-19. Jurnal Konseling dan Pendidikan, 8(2), 98-104.

[22] Naibaho, L. (2014). Peran Pendidikan dan Kebudayaan dalam Pembangunan Karakter dan Peradaban Bangsa Indonesia yang Majemuk. Jurnal the Ary Suta Center Series on Strategic Management, 27(0), 69. 